\title{
Detorgan-迫índia:
}

Telaah Pemikiran Kebangsaan

Volume 3 No 1 Tahun 2021 HImn. 7- 13

Artikel Masuk 26 Juni 2021 I Artikel Diterima 1 September 2021

\section{Membangun Perekonomian Desa Berkelanjutan Melalui Manajemen Kinerja Berbasis Community Empowerment}

\author{
Alif Muhammad Zakaria ${ }^{1}$, Mauliyana Rachmat ${ }^{2}$ \\ ${ }^{1,2}$ Prodi Psikologi Islam, Fakultas Dakwah, Institut Agama Islam Negeri Salatiga \\ 1alifmuzas1307@gmail.com, ${ }^{2}$ rachmat.elmaksum@gmail.com
}

\begin{abstract}
Abstrak
Penelitian ini menggunakan metode analisis kualitatif, data penelitian ini diperoleh dari studi pustaka dan lapangan di Desa Samirono Getasan Kabupaten Semarang. Dengan mencari narasumber yang berkompenten, sumber istansi pemerintah maupun swasta yang mendukung dan relevan. Analisis data dilakukan dengan pendekatan deskriptif yang menguraikan fakta beserta data yang didapat di lokasi penelitian. Hasil Penelitian ini membuktikan bahwa manajemen kinerja berbasis pemberdayaan potensi masyarakat memiliki peran signifikan dalam membangun perekonomian desa berkelanjutan.
\end{abstract}

Kata Kunci : Pemberdayaan Masyarakat, Desa, Manajemen Kinerja.

\begin{abstract}
This study uses qualitative analysis methods, the research data was obtained from literature and field studies in Samirono Getasan Village, Semarang Regency. By looking for competent sources, sources of government and private institutions that support and are relevant. Data analysis was performed with a descriptive approach that outlined the facts along with the data obtained at the study site. The results of this study prove that performance management based on community potential empowerment has a significant role in building a sustainable rural economy.
\end{abstract}

Keywords : Community Empowerment, Village, Performance Management.
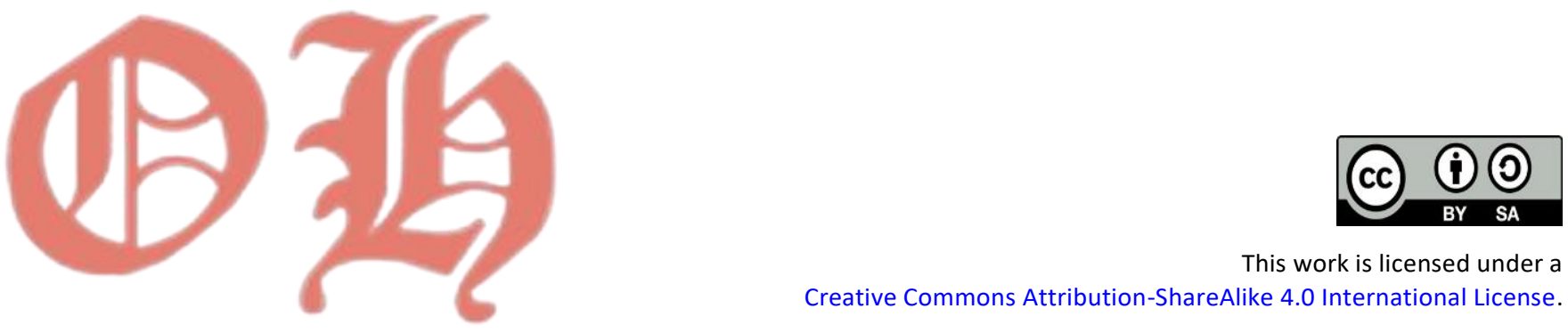
Pemerintah mengupayakan pembangunan disetiap daerah agar seimbang dan serasi. Ketimpangan yang dewasa ini masih dirasa cukup tinggi. Membuat pemerintah melakukan perombakan besar dalam pengelolaan ekonomi. Indonesia merupakan negara dengan tingkat kepadatan penduduk yang tinggi. Hal ini dibuktikan oleh data dari Badan Pusat Statistik (BPS) yang mencatat. Bahwa pada tahun 2019 Indonesia memiliki populasi penduduk sebesar 270 juta jiwa. Yang kemudian menempatkan Indonesia pada posisi ke-empat diantara negara di Dunia. Kepadatan penduduk yang tinggi tanpa adanya upaya penyelesaian serius dan berkala dari Pemerintah. Lewat berbagai sektor tentu akan menimbulkan masalah baru, masalah yang kini timbul diantaranya seperti kemiskinan, kesenjangan sosial dan pengangguran yang masih membengkak. Hal ini dibuktikan bahwa pada tahun 2015 tingkat kemiskinan di Indonesia masih berada pada presentase $11,2 \%$, dengan tingkat pengangguran sebesar 7,05 juta orang. Dari data tersebut kita mengetahui bahwa angka kemiskinan dan pengangguran masih besar. Oleh karena itu pemerintah mulai mencanangkan pembangunan perekonomian desa. Untuk membangun benteng kokoh menuju perekonomian nasional yang berkelanjutan.

Untuk mencapai pembangunan perekonomian yang berkelanjutan maka perlu adanya pemberdayaan masyarakat desa. Pemberdayaan masyarakat desa menjadi hal yang sangat penting, karena desa merupakan tatanan dasar atau fondasi dari suatu Negara. Maju tidaknya perekonomian suatu negara sangat dipengaruhi oleh keadaan ekonominya. Terutama perekonomian yang ada di desa. Oleh karena itu pemberdayaan sumber daya manusia pedesaan dan kesejahteraan masyarakat desa. Secara urgent harus terus ditingkatkan untuk menyiapkan sumber daya manusia. Yang memiliki daya saing serta kualitas untuk menopang perekonomian negara. Terlebih lagi hal ini dapat memberikan dorongan untuk mensukseskan Indonesia emas. Yang digadang pada tahun 2020, atau yang disebut dengan bonus demografi. Secara singkat bonus demografi adalah keadaan dimana usia produktif lebih besar daripada non produktif.

Pembangunan yang berkelanjutan merupakan pembangunan yang masuk dalam aspek sosial, ekonomi, dan lingkungan. Pertumbuhan ekonomi yang baik akan menjadi penentu atau indikator pembangunan suatu negara. Ekonomi sendiri berasal dari bahasa Yunani yaitu Oikos dan Nomos yang berarti rumah tangga, salah satu ahli menyebut ekonomi sebagai aktivitas yang menyangkut kehidupan berkeluarga, secara umum ekonomi adalah bidang yang mempelajari tentang pengurusan sumber daya material individu yang menyebabkan adanya kegiatan ekonomi yaitu produksi, distribusi, dan juga konsumsi.

Perekonomian berkelanjutan memiliki hubungan atau korelasi dengan pembangunan berkelanjutan, menurut Emil Salim (1990) pembangunan berkelanjutan memiliki tujuan yaitu meningkatkan kesejahteraan masyarakat, kemudian KLH (1990) yang merujuk pada perekonomian berkelanjutan mengungkapkan bahwa perekonomian berkelanjutan terkait dengan produksi, distribusi, dan konsumsi harus berdampak positif bagi lingkungan (tidak ada polusi), tidak adanya pemborosan sumber daya alam, dan kegiatanya harus bisa member manfaat yang besar bagi kesejahteraan antar generasi.

Alasan mengapa perekonomian harus berkelanjutan adalah menyangkut alasan moral, alasan moral tersebut merupakan suatu tanggung jawab atas sumber daya yang digunakan agar generasi mendatang juga dapat memanfaatkanya, alasan kedua adalah alasan ekologi, keanekaragaman hayati yang ada misalnya, para pelaku ekonomi tidak boleh merusak fungsi dari keragaman ini, yang ketiga adalah alasan ekonomi, seperti hari ini kita belum mengetahui secara pasti apakah semua kegiatan ekonomi menerapkan ekonomi yang berkelanjutan atau belum, maka kita sebagai generasi hari ini harus menggunakan sumber daya alam secara wajar.

Kinerja secara harafiah dapat dimaknai sebagai kontribusi dan prestasi yang diperoleh individu atau karyawan setelah individu yang bersangkutan melakukan suatu tindakan, Berbicara perihal pemberdayaan dan juga kinerja pasti akan dibarengi dengan pembahasan tentang manajemen. Manajemen sendiri memiliki pengertian tindakan kerjasama yang dilakukan antara sekelompok orang atau individu serta unsur-unsur sumber daya lain yang ada dalam organiasi guna pencapaian tujuan.

Secara fundamental atau mendasar manajemen kinerja adalah hasil kerja menyeluruh atas apa yang dicapai oleh individu lewat pekerjaan atau tanggung jawab yang dibebankan seorang yang berwenang kepadanya, oleh sebab itu manajemen kinerja merupakan elemen yang sangat 
urgent dalam pengelolaan sumber daya manusia karena manajemen kinerja memiliki fungsi sebagai titik acuan pengevaluasian kinerja individu terhadap pencapaian tujuan yang telah disusun sebelumnya. Secara definitif manajemen kinerja merupakan kegiatan atau proses untuk mengelola dan megevaluasi kinerja yang ada, baik dalam organisasi atau masyarakat agar lebih tepat guna dan produktif guna menunjang, meningkatkan, memperbaiki dalam proses atau keberhasilan pencapaian tujuan.

Tujuan Utama Manajemen Kinerja. Purpose atau tujuan utama manajemen kinerja adalah meningkatnya kinerja yang dihasilkan dari organisai, kelompok tim, atau individu agar tercapainya tujuan yang telah ditetapkan jauh-jauh hari. Menurut Wibowo (2010) tujuan dari manajemen kinerja dibagi menjadi 3 (tiga) bagian utama : Pertama Tujuan Stratengik, Dalam tujuan ini manajemen kinerja memiliki korelasi atu berhubungan sangat erat dengan proses atau kegiatan individu sesuai dengan acuan untuk mengukuhkan pencapaian tujuan yang ditetapkan. Pelaksanaan strategi ini memerlukan kejelasan yang tinggi mengenai hasil yang ingin dicapai, perilaku, mengetahui karakteristik yang diperlukan, pengembangan pengukuran, dan sistem feedback atau umpan-balik bagi kinerjanya. Kedua Administrative Purpose, Tujuan administratif merupakan hubungan antara kinerja dan evaluasi kerja yang telah lewat, hal ini berguna untuk memberikan keputusan terkait administratif seperti pengkajian pengevaluasian, ketepatan promosi, dan lain-lain. Ketiga Development Purpose, Manajemen kinerja juga memiliki titik tujuan untuk melakukan pengembangan kapasitas individu yang memiliki berbagai potensi terutama potensi pada tanggung jawab pekerjaanya, selain itu lewat tujuan ini pula pihak berwenang bisa menyiasati dengan pemberian pelatihan yang sesuai bagi individu yang memiliki kinerja tidak maksimal atau kurang produktif, lewat development purpose ini pula dapat serta menempatkan individu pada posisi yang tepat agar kinerja mereka sesuai dengan potensi yang dimiliki.

Komponen Dalam Manajemen Kinerja. Berdasarkan dari definisi manajemen kinerja yang menyebutkan bahwasanya manajemen kinerja ialah berbagai bentuk perilaku atau aktivitas yang dilakukan oleh manajer dimana hal tersebut bersifat kompleks serta melibatkan berbagai unsur dan komponen yang ada dalam organisasi yang terhubung satu dengan lainnya. Lalu apa saja komponen dalam manajemen kinerja ? komponen atau unsur yang dimaksud adalah :

Planning, Pemberdayaan yang baik adalah pemberdayaan yang memiliki rencana sebelum terjun atau menerapkanya ke lapangan hal ini dapat dilakukan dengan perencanaan secara terperinci dan mendetail tentang semua pekerjaan sebelum pekerjaan tersebut dilakukan atau dalam kata lain disebut dengan penyusunan Job Description. Perencanaan tersebut berguna bagi patokan atau pedoman dalam mewujudkan tujuan yang telah disepakati sebelumnya. Berdasarkan paparan tersebut maka kerja individu akan menjadi terorganisir dan jelas, mereka akan tahu hal apa yang harus mereka kerjakan, terarah kepada tujuan awal atau tujuan yang telah ditetapkan.

Pengawasan, Monitoring atau pengawasan terhadap kinerja harus dilakukan untuk mengetahui seberapa besar motivasi dan hasil kerja, dari hal ini diharapkan apabila ditemui individu dengan hasil kerja rendah ia akan dibantu untuk kemudian memiliki hasil kerja yang produktif, monitoring juga berfungsi sebagai tolok ukur kemampuan dalam menyelesaikan tanggung jawab ang dibebankan kepadanya.

Pengembangan, Pengembangan berfungsi sebagai pemberian skill baik soft atau hard, hal ini dimaksudkan agar dapat mengembangkan dirinya, pengembangan diri ini masih dalam kategori yang berhubungan dengan pekerjaan, pengembangan diri ini dapat dicapai dengan pelatihan-pelatihan yang diberikan dari pemerintah. Pemberdayaan yang baik tidak hanya mementingkan produktivitas, visi, misi saja melainkan pengembangan potensi individu tersebut.

Pemberian Hadiah (Reward), Pemberian hadiah atau rewarding atas prestasi atau kinerja yang baik menjadi komponen yang harus adai, hal ini akan memupuk persaingan sehat yang mengacu pada kinerja dan produktifitas.

Pemberdayaan Potensi Masyarakat (Community Empowerment). Pemberdayaan masyarakat adalah suatu konsep pembangunan ekonomi yang didalamnya merangkum asas dan nilai-nilai masyarakat yang bersifat partisipatif, berpusat pada individu, dan berkelanjutan. Community empowerment atau pemberdayaan potensi masyarakat menurut Kuswandoro adalah 
pemberdayaan potensi yang sudah dimiliki oleh masyarakat lewat kebebasan yang dilimpahkan kepada individu untuk mengoptimalkan potensi yang dimiliki, bertanggungjawab secara penuh serta memiliki kewenangan untuk menentukan perubahan yang berdampak pada pencapaian sasaran.

Berangkat dari pemaparan diatas peneliti memfokuskan masalah. Apakah pola manajemen berbasis community empowerment atau pemberdayaan potensi masyarakat desa. Yang telah diterapkan memiliki peran yang signifikan, terhadap pembanguan perekonomian desa yang berkelanjutan dan penyelesaian permasalahan kemiskinan serta pengangguran. Dalam hal ini peneliti memilih Desa Samirono yang terletak di Getasan Kabupaten Semarang sebagai tempat observasi guna menggali informasi yang tepat dan akurat sesuai dengan keadaan lapangan.

Desa Samirono merupakan Desa yang memiliki potensi pengelolaan sampah plastik menjadi barang kreatif yang bernilai ekonomis. Penelitian yang hampir serupa sebelumnya telah dilakukan oleh Edriana Pangestuti Dkk. dengan judul "Peta Potensi Dalam Menciptakan Kemandirian Ekonomi Desa (Studi Pada Desa Tawang Argo, Malang)" yang kemudian menghasilkan peta potensi pengelolaan jamur dengan pembangunan kumbung jamur sebagai usaha yang memiliki nilai ekonomis dan daya saing. Selain itu Supartini juga melakukan penelitian yang hampir serupa dengan judul "Pemberdayaan Masyarakat Melalui Pengembangan Potensi Desa Wisata Ketingan Kabupaten Sleman-DI Yogyakarta" hasil penelitian ini menunjukkan bahwa potensi desa wisata Ketingan yang ada di beberapa sektor sudah berjalan dengan baik namun masih belum secara utuh mandiri.

\section{Metode}

Penelitian ini merupakan penelitian kualitatif dengan metode analisis deskriptif yang dilakukan di Desa Samirono Getasan Kabupaten Semarang, pemilihan penelitian kualitatif dengan metode ini dimaksudkan agar bahan kajian lebih komprehensif dan mendetail dikarenakan hal tersebut masih dalam tahapan asumsi-asumsi yang perlu dibuktikan secara fakta sesuai dengan keadaan di lapangan.

Terdapat data primer dan sekunder pada penelitian ini, adapun teknik pengumpulan data yang dilakukan peneliti adalah observasi dan wawancara (indepth-interview) dengan subjek penelitian yang terdiri dari 4 (empat) orang yang memiliki peranan penting dalam pengelolaan sampah plastik yaitu : Kepala desa, Pengrajin sampah plastik (2 Orang) dan Ketua Tempat Pembuangan Sampah Akhir (TPS). Sedangkan data sekunder dari penelitian ini adalah dokumentasi berupa pemilahan sampah plastik dan produk jadi dari kerajinan sampah plastik yang memiliki nilai ekonomis. Untuk mempertahankan tanggungjawab akademis dan mempertahankan kredibilitas maka peneliti juga melakukan triangulasi data antara data primer dengan sekunder agar apa yang nanti dikemukakan sesuai dengan apa yang terjadi di lapangan.

\section{Hasil Dan Pembahasan}

Fokus utama penelitian ini bertujuan untuk mengetahui seberapa kuat pola manajemen kinerja berbasis empowerment dalam membangun perekonomian desa yang berkelanjutan di Desa Samirono Getasan Kabupaten Semarang serta mengetahui apakah manajemen berbasis community empowerment mampu mengurangi masalah kemiskinan dan pengangguran di desa tersebut, selain itu penelitian ini juga bertujuan memberikan follow-up terhadap program Pemerintah yang telah berjalan sebelumnya, penelitian ini juga bertujuan untuk memberikan sumbangsih komprehensif kepada peneliti selanjutnya yang mungkin akan mengambil fokus penelitian serupa yaitu pembangunan pemberdayaan masyarakat terhadap kemajuan pembangunan perekonomian desa yang mungkin kedepan akan dikaji lebih mendalam lewat berbagai macam sektor dan basis sosial. 
Tempat Pembuangan Sampah (TPS) Mranggen yang terletak di Dusun Tawang Desa Samirono merupakan tempat dimana Sampah-sampah dipilah untuk kemudian disimpan dan dijadikan bahan yang siap dikreasikan oleh pengrajin di daerah Desa Samirono Getasan. Berikut mekanisme pengelolaan sampah dari TPS hingga menjadi produk kreatif yang bernilai ekonomis.

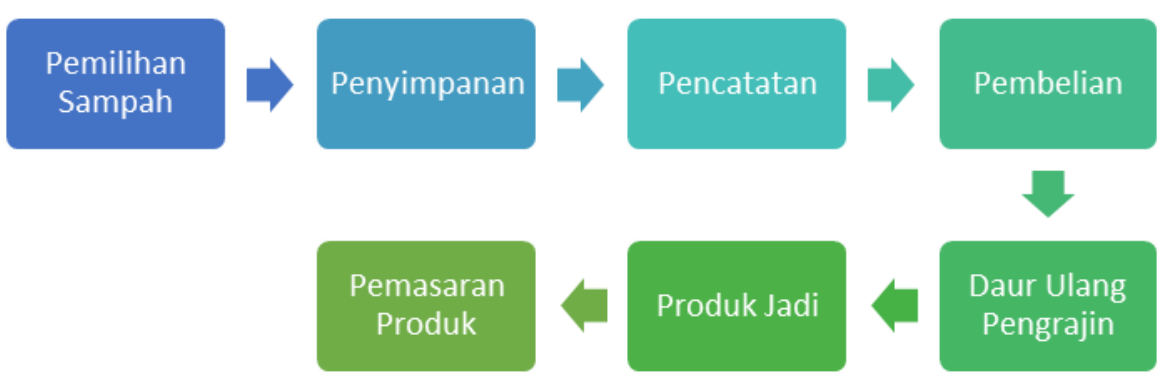

Tabel 1.1 Mekanisme Pengelolaan Sampah

Tahap pertama adalah memilah sampah yang dilakukan oleh pekerja yang ada di TPS Mranggen, setelah sampah dipilah menurut jenis dan harga yang telah ditentukan selanjutnya sampah tersebut disimpan, sebelum disimpan sampah-sampah yang telah dipilah tersebut ditimbang dan dicatat oleh pengurus. Selanjutnya para pengepul sampah atau pengrajin datang ke TPS untuk membeli sampah yang sudah dipilah tersebut.

Menurut Ketua Tempat Pembuangan Sampah (TPS) Mranggen pada tahun 2016 pemberdayaan masyarakat Desa Samirono belum terlalu gencar oleh karena itu perkembangan kerajinan sampah menjadi produk kreatif di Desa Samirono masih belum berkembang dengan maksimal. Kemudian pada tahun 2017 para pengrajin berinisiatif membentuk komunitas atau lembaga yang mewadahi mereka untuk berkomunikasi dan mengembangkan pemasaran kerajinan mereka, setelah berdiri kurang lebih 1 (satu) tahun Pemerintah mulai melihat potensi yang dimiliki oleh masyarakat Desa Samirono, oleh karena itu pada tahun 2019 awal, Pemerintah daerah memberikan pelatihan tata cara manajemen kinerja yang baik bagi TPS dan pengrajin.

Setelah itu pelatihan tahap awal itu selesai selanjutnya pemerintah memberikan kewenangan seluas-luasnya kepada masyarakat sekitar untuk mengelola sampah dan melakukan evaluasi setiap bulan dalam rangka memberikan arahan dan kemajuan dari sektor tersebut, disisi lain pemerintah juga melakukan pembinaan pemberdayaan masyarakat yang mulai berminat lewat pelatihan-pelatihan pengelolaan sampah menjadi barang yang bernilai ekonomis, alhasil dari keseriusan ini, program pemberdayaan masyarakat desa Samirono berjalan hingga sekarang dan tentu menghasilkan peningkatan pendapatan dan juga kesejahteraan bagi masyarakat desa setempat selain itu pemasaran hasil kerajinan tersebut semakin meluas hingga ke berbagai daerah di Pulau Jawa dan Bali.

Kepala Desa Samirono mengatakan bahwa tingkat pendidikan di Desa ini masih rendah; rata-rata lulusan Sekolah Menengah Pertama (SMP) tetapi setelah adanya program pemerintah yang mencanangkan pemberdayaan desa untuk membangun perekonomian berkelanjutan ini berdampak positif, hal ini dibuktikan dengan berkurangnya angka pengangguran di Desa tersebut. Hasil wawancara dengan salah satu pengrajin sampah bernama Rakhmat mengungkapkan bahwa Ia bisa memiliki pendapatan bersih hingga Rp.1.00.000,00 setiap bulan dengan modal awal Rp.300.000,00 hanya dari penjualan berbagai jenis kerajinan yang ia buat. Selanjutnya Siti yang juga seorang pengrajin sampah mengatakan bahwa kini telah banyak pengrajin baru yang terjun ke lapangan untuk mendapatkan tambahan pendapatan dikarenakan proses pembuatan yang fleksibel-tidak terikat oleh waktu.

Upaya Pemerintah dalam Pemberdayaan Pengrajin Desa Samirono. Dewasa ini usaha atau upaya-upaya pemberdayaan masyarakat itu mulai dilakukan oleh Pemerintah. Pemerintah mulai gencar dan memfokuskan pada manajemen kinerja berbasis kemandirian potensi masyarakat pedesaan atau yang disebut dengan community empowerment. Manajemen 
kinerja sendiri merupakan proses yang terorganisir dalam melakukan pengevaluasian terhadap produktivitas individu menurut tanggungjawab yang dilimpahkan dari atasan atau orang yang berwenang.

Memaksimalkan potensi masyarakat yang ada di desa merupakan kunci untuk membangun perekonomian yang berkelanjutan, pengembangan potensi ini dapat berupa pengembangan desa wisata, memperbesar Badan Usaha Milik Desa (BUMdes) serta memperkuat UMKM atau home industry yang ada di Desa. Manajemen kinerja berbasis community empowerment ini berkaitan erat dengan kesejahteraan masyarakat desa dan pemberdayaan sumber daya manusianya, maka keseriusan Pemerintah menjadikan desa sebagai garda terdepan dalam membangun perekonomi berkelanjutan diperkuat pada tahun 2017 oleh Menteri Keuangan Sri Mulyani dalam Undang-undang desa yang menyatakan bahwa desa memiliki otoritas otonom untuk mengelola sumber-sumber dana yang digelontorkan guna meningkatkan sumber daya manusia dan kesejahteraan masyarakat desa.

Jika ditinjau dari hasil penelitian yang didapat dari lapangan, peran pemerintah lewat pemberdayaan potensi masyarakat atau manajemen kinerja berbasis community empowerment terkhusus bagi pengrajin di Desa Samirono sudah sangat baik, hal ini terbukti dari berkurangnya angka pengangguran dan meningkatnya pendapatan masyarakat di Desa tersebut, seperti yang kita ketahui bahwa community empowerment adalah pengembangan potensi yang sudah dimiliki oleh masyarakat lewat hak yang dilimpahkan kepada individu untuk mengoptimalkan potensi yang dimiliki, bertanggungjawab secara penuh serta memiliki kewenangan untuk menentukan perubahan yang berdampak pada pencapaian sasaran maka pola manajemen kinerja berbasis hal tersebut sudah berjalan dengan baik. Kesungguhan pemerintah dalam pengembangan atau pemberdayaan masyarakat tersebut pun dibuktikan dengan adanya pelatihan-pelatihan yang menunjang potensi masyarakat untuk turut serta andil dalam bagian pengelolaan sampah menjadi barang yang berdaya saing dan memiliki nilai ekonomis.

Ekonomi Berkelanjutan Desa Samirono. Community empowerment atau yang disebut sebagai pemberdayaan potensi masyarakat adalah metode yang digadang pemerintah untuk pembangunan berkelanjutan, dalam hal ini pada bidang ekonomi, warga Desa Samirono telah menerapkan pola atau mengimplementasikan teori pembangunan perekonomian yang berkelanjutan, pengelolaan sampah plastik yang dilakukan merupakan upaya untuk menjadikan sampah menjadi barang yang bernilai jual, dimana kita mengetahui bahwa sampah plastik tidak mudah terurai oleh tanah maka dengan adanya pengelolaan limbah atau sampah plastik ini, lingkungan akan menjadi menjadi lebih bersih, selain itu kesejahteraan yang ditimbulkan dari pengelolaan sampah ini nampak member peran positif yaitu mengurangi pengangguran dan kemiskinan, warga desa menjadi mandiri dengan memproduksi dan menjual kerajinan mereka hingga keluar daerah bahkan luar provinsi.

\section{Simpulan}

Pembangunan perekonomian desa berkelanjutan dengan basis pemberdayaan potensi masyarakat desa memiliki peran yang sangat besar guna mengatasi masalah kemiskinan dan pengangguran di Indonesia apabila program pemberdayaan ini diterapkan, hal ini dibuktikan dengan hasil penelitian yang menemukan bahwa lewat program pemerintah dari pelatihan yang diberikan dengan basis pemberdayaan potensi masyarakat di Desa Samirono dapat mengurangi angka kemiskinan dan juga pengangguran di desa tersebut, selain itu kegiatan ini pun memberikan keuntungan dalam hal perekonomian berkelanjutan seperti pemeliharaan ekonomi, sosial, dan lingkungan, keunggulan dari manajemen berbasis community empowerment ini adalah adanya sumber daya manusia yang telah berjalan sebelumnya sehingga pemerintah tinggal mengembangkan atau memberdayakan potensi yang ada pada masyarakat desa tersebut, ada pun kekurangan dalam manajemen berbasis hal tersebut adalah perlunya pendampingan secara berkala dan terus menerus sampai masyarakat paham dan mengetahui bagaimana tata cara manajemen yang baik dan efisien. 
Daftar Pustaka

Candra Kusuma Dkk. 2013. "Pengelolaan Alokasi Dana Desa Dalam Pemberdayaan Masyarakat Desa: Studi pada Desa Wonorejo Kecamatan Singosari Kabupaten Malang)". Jurnal Ilmiah. Universitas Brawijaya Malang: Malang.

Dickdick Sodikin, Djaka Permana, dan Suhenda Adia. 2017. "Manajemen Sumber Daya Manusia: Membangun Paradigma Baru".Jakarta: Salemba Empat

Edriana Pangestuti Dkk ,2018, "Peta Potensi Dalam Menciptakan Kemandirian Ekonomi Desa (Studi Pada Desa Tawang Argo,Malang)". Journal of Applied Business Administration Vol 2, No 2, Malang. Universitas Brawijaya.

https://id.m.wikipedia.org/wiki/Kemiskinan_di_Indonesia\#cite_ref-2 diakses pada 26 Februari 2020 pada pukul 20:43 WIB.

https://m.cnnindonesia.com/ekonomi/20191105154437-532-445788/angka-pengangguran-naikjadi-705-juta-orang-per-agustus-2019 diakses pada 26 februari 2020 pada pukul 20:44 WIB.

https://www.bps.go.id/publication/2019/07/04/daac1 ba18cae1e90706ee58a/statistik-indonesia2019.html diakses pada 26 Februari 2020 pukul 20:35 WIB.

Jaya Askar. 2004. "Konsep Pembangunan Berkelanjutan (Sustainable Development). Jurnal. Institut Pertanian Bogor : Bogor.

Kuswandoro, Wawan E. 2016. "Strategi Pemberdayaan Masyarakat Desa Berbasis Partisipasi". Malang. Universitas Brawijaya.

Luthfia Rizka, A. 2013. "Menilik Urgensi Di Era Otonomi Daerah". Journal of Rural and Development. Vol IV, no 2.

M. Alamsyah, Nur. 2011. "Memahami Perkembangan Desa di Indonesia". Jurnal Academica Fisip Unitad. Vol 03.

Noor Munawar. 2011. "Pemberdayaan Masyarakat. Jurnal Ilmiah CIVIS Vol 1 No 2.

Poltak, Lijan Sinambela. 2012. "Kinerja Pegawai”. Yogyakarta: Graha Ilmu.

Pratiwi Dkk. 2018. "Analisis Implementasi Pembangunan Berkelanjutan Di Jawa Timur". Jurnal vol 18 No 1. Universitas Brawijaya: Malang.

Sri Mulyani Indrawati. 2017. "Buku Pintar Dana Desa". Jakarta: Direktorat Jenderal Perimbangan Keuangan.

Sugiyono. 2012. "Metode Penelitian Kombinasi (Mix Methods). Bandung: Alfabeta.

Supartini.2012. "Pemberdayaan Masyarakat Melalui Pengembangan Potensi Desa Wisata Ketingan Kabupaten Sleman-DI Yogyakarta". Yogyakarta. Akademi Maritim. Jurnal Nasional Pariwisata, Vol. 4, Nomor 1.

Syafaruddin. 2005. “Manajemen Lembaga Pendidikan Islam”. Jakarta: Ciputat Press.

T. Gilarso. 2004. "Pengantar Ilmu Ekonomi”. Yogyakarta: Kansius.

Wasisto Raharjo Jati,2015, “Bonus Demografi Sebagai Mesin Pertumbuhan Ekonomi: Jendela Peluang Atau Jendela Bencana Di Indonesia?”, Yogyakarta. Universitas Gadjah Mada dapat diakses melalui https://jurnal.ugm.ac.id/populasi/article/view/8559/6591

Wibowo. 2010. "Manajemen Kinerja”.Jakarta: Rajawali Press. 